\title{
Molekylær diagnostikk av maligne lymfomer
}

\begin{abstract}
Sammendrag
Bakgrunn. Maligne lymfomer er en heterogen gruppe av ikke-solide svulster som har sitt opphav i lymfocytter på ulike differensieringstrinn. Diagnosen baseres på tradisjonell histopatologisk diagnostikk supplert med immunfenotyping, cytogenetikk, molekylærgenetiske metoder og kliniske opplysninger. I denne artikkelen omtales utprøvende molekylær diagnostikk, i hovedsak basert på mikromatrisebasert genekspresjonsteknologi.
\end{abstract}

Materiale og metode. Vi omtaler resultater som er oppnådd gjennom et internasjonalt samarbeidsprosjekt, ledet av det nasjonale kreftforskningsinstituttet i USA (National Cancer Institute), der Radiumhospitalet deltar som eneste senter fra Norden. Funnene er diskutert i relasjon til andre studier i feltet, basert på et ikke-systematisk litteratursøk i PubMed.

Resultater. Det er påvist klinisk relevante nye undergrupper av B-cellelymfomer, og i retrospektive overlevelsesanalyser er det kartlagt hvordan genuttrykksmønsteret korrelerer med prognose. I tillegg har studiene bidratt til viktig og ny biologisk kunnskap som gir grunnlag for ny målrettet behandling som er under utprøving i kliniske studier.

Fortolkning. Molekylær diagnostikk gir, som supplement til dagens diagnostikk, en bedret diagnostisk presisjon og åpner muligheter for nye behandlingsmetoder til pasienter med maligne lymfomer.

\section{Harald Holte}

harald.holte@radiumhospitalet.no

Stein Kvaløy

Kreftklinikken

Oslo universitetssykehus, Radiumhospitalet

\section{Jan Delabie}

Patologiklinikken

Oslo universitetssykehus, Rikshospitalet

Universitetet i Oslo

\section{Gunhild Trøen}

Patologiklinikken

Oslo universitetssykehus, Rikshospitalet

\section{Erlend B. Smeland}

Avdeling for immunologi

Institutt for kreftforskning

Oslo universitetssykehus, Radiumhospitalet og

Senter for kreftbiomedisin

Fakultetsdivisjonen Radiumhospitalet

Universitetet i Oslo

Maligne lymfomer er en heterogen gruppe av ondartede svulster som utgår fra lymfocytter. I dag foreligger det en internasjonal histologisk klassifikasjon som brukes over hele verden (1). Denne tar utgangspunkt i både histologisk morfologi, uttrykk av linjespesifikke proteiner på celleoverflaten eller intracellulært påvist ved immunhistokjemisk metode eller væskestrømsmåling, eventuelt supplert med cytogenetikk og/ eller molekylærgenetiske undersøkelser og kliniske opplysninger (fig 1). Ved moderne diagnostikk der alle hjelpemidlene angitt over, tas i bruk og tolkes av patolog med erfaring og kunnskap om maligne lymfomer, er diagnosen langt sikrere enn for få år siden. Dette er av interesse ettersom behandlingen av maligne lymfomer i dag er svært differensiert.

Ved molekylær diagnostikk er det i dag mulig å undersøke RNA-uttrykk (ekspresjon) og DNA- sekvensen av hele eller deler av genomet, det siste for å kartlegge delesjoner, amplifikasjoner, translokasjoner og mutasjoner. I denne artikkelen omtales molekylære studier på ulike lymfomtyper med vekt på studier av genekspresjon ved mikromatriseteknologi

\section{Materiale og metode}

Artikkelen oppsummerer sentrale resultater til gruppen ledet fra NCI med norsk deltakelse gjennom Radiumhospitalet (LLMPPprosjektet) og relaterer disse funnene til resultater andre grupper har kommet frem til. Grunnlaget for omtale av andre arbeider innen dette feltet er et ikke-systematisk littera- tursøk i PubMed, med et skjønnsmessig utvalg av artikler basert på forfatternes erfaringer innen feltet.

\section{Epidemiologi og klinisk forløp}

Maligne lymfomer inndeles i Hodgkins (120 nye tilfelle per år i Norge) og non-Hodgkins lymfom (ca. 800 nye tilfeller per år i Norge). Non-Hodgkins-lymfomene deles igjen inn i B-cellelymfomer og T-cellelymfomer hvorav den førstnevnte gruppen utgjør ca. $85 \%$. I tabell 1 vises de vanligste undergruppene av maligne lymfomer med frekvens, vanligste behandling, behandlingsmål og -resultat i form av kurasjonsrate og median overlevelse (2). Som det fremgår er det store variasjoner mellom de ulike undergruppene. Det er også store variasjoner i det kliniske bildet og forløpet etter behandlingsstart innen de ulike gruppene selv om pasientene gis den samme behandlingen. Kun noe av denne forskjellen kan forklares ved karakteristika ved svulsten (sykdomsutbredelse, blodprøver som hemoglobinkonsentrasjon eller LDH) og pasienten (alder, funksjonsstatus) (3-5).

\section{Molekylær diagnostikk - metoder og hensikt}

I våre og andres studier er genuttrykk undersøkt ved hjelp av RNA-mikromatriser, som tidligere beskrevet i Tidsskriftet (6). I en del av studiene har man også undersøkt amplifikasjoner og delesjoner av gener ved genomiske mikromatriser som eventuelt kunne forklare de karakteristiske genuttrykkene. Videre kan man ved hjelp av immunhistokjemisk undersøkelse finne ut om den karakteristiske molekylære signaturen også vises ved uttrykk av spesifikke proteiner. Hensikten med disse studiene er å:

- Sikrere diagnostikk innenfor vår nåværende klassifikasjon

- Undersøke om det foreligger nye undergrupper av klinisk betydning

\section{Hovedbudskap}

- Viktige nye subtyper av maligne lymfomer er identifisert

- Ny kunnskap om lymfomenes biologi er avdekket

- DNA-mikromatriseanalyser kan bli et viktig supplement til morfologisk rutinediagnostikk 
- Relatere genuttrykket til pasientoverlevelse og behandlingsrespons

- Påvise spesifikke endringer i lymfomcellene som er essensielle for lymfomcellenes vekst og overlevelse og som kan være gjenstand for ny og bedre målrettet behandling

\section{LLMPP-prosjektet}

Biopsiene av aktuelle pasienter sendes til NCI i nedfryst tilstand. Følgende undergrupper av maligne lymfomer har vært analysert til nå: diffuse storcellede B-cellelymfomer (DLBCL) (7), mantelcellelymfomer (MCL) (8), primære mediastinale B-cellelymfomer (9) (PMBCL), follikulære lymfomer (FL) (10) og Burkitts lymfom (BL) (11).

\section{Molekylær diagnostikk av viktige lymfomtyper}

Diffuse storcellede B-cellelymfomer

I en stor retrospektiv undersøkelse av biopsier fra 240 pasienter med DLBCL ved bruk av DNA-mikromatriser (7), ble funn fra en mindre forstudie (12) bekreftet; DLBCL består av to hovedgrupper, aktivert B-celle (activated B-cell, ABC) og germinalsenter B-celle (germinal center B-cell, GCB) med forskjellig genuttrykksmønster. Til sammen 12916 gener ble analysert, og utvalget var basert på at disse genene er spesielt høyt uttrykt i lymfoide celler, kreftceller generelt og i gener som er relatert til immunresponser. 100 gener ble vist å være uttrykt ulikt i $\mathrm{ABC}$ - versus GCB-undergruppene. Ett sett av gener var således høyt uttrykt $i$ germinalsentercellegruppen og lavt i den aktiverte Bcellegruppen, mens for et annet sett var det omvendt. Noen biopsier hadde en genprofil

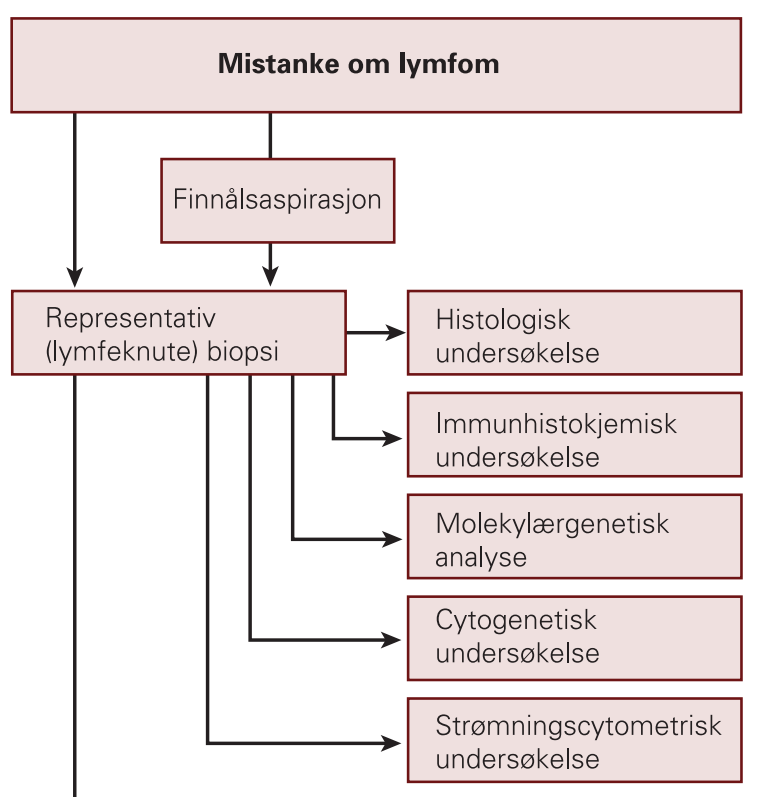

Beinmargsbiopsi

Beinmargsutstryk

Perifert blodutstryk

Strømningscytometrisk

undersøkelse av

blod og beinmarg

Cytogenetisk

undersøkelse av

blod og beinmarg

Figur 1 Histopatologisk utredning av maligne lymfomer

Tabell 1 Karakteristika ved noen histologiske typer non-Hodgkins lymfom

\begin{tabular}{|c|c|c|c|c|c|}
\hline Typer & $\begin{array}{l}\text { Andel } \\
\text { i prosent }\end{array}$ & Veksthastighet & Behandlingsmål1 & 1. linje cytostatikabehandling & $\begin{array}{l}\text { Median over- } \\
\text { levelse (år) (2) }\end{array}$ \\
\hline B-cellelymfom & 86 & & & & \\
\hline Diffust storcellet & 35 & $\mathrm{H} \varnothing y$ & Kurasjon & $\mathrm{CHOP}^{2}$ analoge med rituximab & 5 \\
\hline Mantelcelle & 6 & Høy, varierende & Livsforlengende & $\begin{array}{l}\mathrm{CHOP}^{2} \text { med rituximab alternerende med } \\
\text { høydose cytosar med rituximab, ev. } \text { HMAS }^{3}\end{array}$ & 3 \\
\hline Marginalsone & 10 & Lav & $\begin{array}{l}\text { Livsforlengende. Kurasjon } \\
\text { oppnås ved } \mathrm{MALT}^{4} \text { type, } \\
\text { begrenset }\end{array}$ & Klorambucil monoterapi/rituximab & 15 \\
\hline Follikulært & 25 & Lav, varierende & Livsforlengende & $\begin{array}{l}\mathrm{COP}^{5} \text { eller } \mathrm{CHOP}^{2} \text { med rituximab, } \\
\text { rituximab, klorambucil }\end{array}$ & 10 \\
\hline Burkitt, Burkitt-likt & 3 & Svært høy & Kurasjon & GM-ALL B ALL/NHL $2002^{6}$ m/rituximab & 5 \\
\hline B-lymfoblast & $<1$ & Svært høy & Kurasjon & Hammersmith, modifisert & 0,5 \\
\hline$T$ - cellelymfom ${ }^{7}$ & 14 & & & & \\
\hline Perifert & 4 & Høy, varierende & Kurasjon & $\mathrm{CHOP}^{2}$ (evt. med $\mathrm{HMAS}^{3}$ ) & 2 \\
\hline Storcellet anaplastisk & 2 & $\mathrm{H} \varnothing y$ & Kurasjon & $\mathrm{CHOP}^{2}$ (evt. med $\mathrm{HMAS}^{3}$ ) & 7 \\
\hline $\begin{array}{l}{ }^{1} \text { Gjelder for pasienter med } \\
{ }^{2} \text { Kombinasjonsterapi med c } \\
{ }^{3} \text { Høydosebehandling med at } \\
{ }^{4} \text { Mucosa-associated lympho } \\
{ }^{5} \text { Kombinasjonsterapi med c } \\
{ }^{6} \text { Handlingsprogram for diag } \\
\text { Selskap for Hematologi og } \\
{ }^{7} \text { T-cellelymfomer er svært }\end{array}$ & $\begin{array}{l}\text { edt sykdom } \\
\text { fosfamid, do } \\
\text { og stamcelle } \\
\text { issue } \\
\text { fosfamid, vi } \\
\text { tikk og beha } \\
\text { rsk Lymfoms } \\
\text { rogene. To t }\end{array}$ & $\begin{array}{l}\text { med alder og allm } \\
\text { sorubicin, vinkristin } \\
\text { tøtte } \\
\text { kristin og prednison } \\
\text { dling av akutt lymfol } \\
\text { uppe } \\
\text { er er nærmere spe }\end{array}$ & $\begin{array}{l}\text { astisk leukemi/lymfoblastisk lym } \\
\text { isert }\end{array}$ & om og Burkitts lymfom/leukemi hos voksne. Utarbe & idet av Norsk \\
\hline
\end{tabular}


a

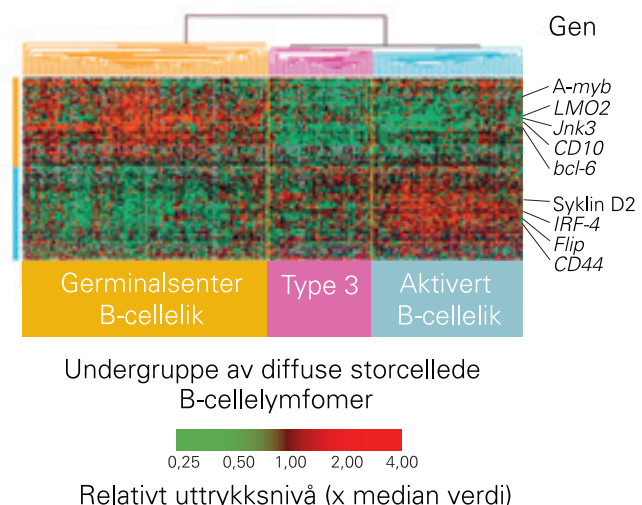

b

\begin{tabular}{|c|c|c|c|}
\hline & $\begin{array}{l}\text { Germinalsenter } \\
\text { B-cellelik }\end{array}$ & Type 3 & Aktivert B-cellelik \\
\hline Onkogen endring & \multicolumn{3}{|c|}{ Antall prøver } \\
\hline C-rel-amplifikasjon & 17 & 0 & 0 \\
\hline$b c l-2$ t $(14 ; 18)$ & 26 & 0 & 0 \\
\hline
\end{tabular}

c

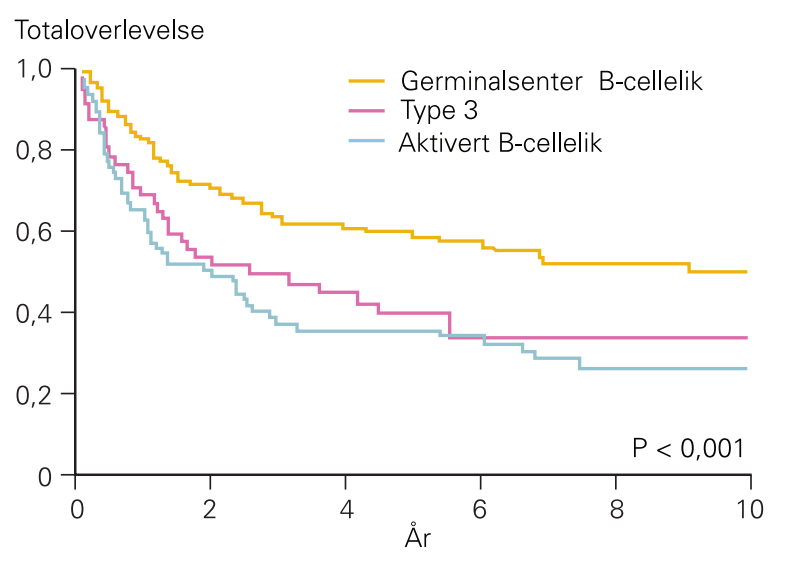

\section{Antall i live}

$\begin{array}{lccccrr}\text { Germinalsenter B-cellelik } & 115 & 81 & 60 & 46 & 32 & 19 \\ \text { Type 3 } & 52 & 24 & 18 & 10 & 8 & 5 \\ \text { Aktivert B-cellelik } & 73 & 35 & 23 & 19 & 8 & 5\end{array}$

Figur 2 Undergrupperav diffuse storcellede B-cellelymfomer basert på genuttrykksprofil. a) Hierarkisk baserte klynger av diffuse storcellede B-cellelymfomer fra 240 pasienter med ubehandlet sykdom og 34 pasienter som tidligere var behandlet eller som hadde lavgradig malignt lymfom fra tidligere, inndelt etter grad av uttrykk av 100 gener. Røde områder indikerer økt uttrykk og grønne områder redusert uttrykk. Hver kolonne representerer et enkelt lymfom, og hver rad representerer et enkelt gen. Gener som er karakteristisk uttrykt i germinalsenter B-cellelikt diffust storcellet Bcellelymfom eller aktivert $B$-cellelikt diffust storcellet B-celle lymfom er indikert. Dendrogrammet på toppen viser i hvilken grad hvert diffust storcellet B-cellelymfom er beslektet med de andre med henblikk på genuttrykk. b) Antall prøver med amplifikasjon av c-rel-lokus og bcl-2-translokasjoner i undergrupper av diffuse storcellede B-cellelymfomer basert på polymerasekjedereaksjonsanalyse. c) Kaplan-Meier-estimater av totaloverlevelse etter kjemoterapi for 240 tidligere ubehandlede pasienter, inndelt etter undergrupper basert på genuttrykk. Rosenwald og medarbeidere (7) (c) [2009] Massachusetts Medical Society, gjengitt med tillatelse

der ingen av disse gensettene var høyt uttrykt, og disse ble kalt type 3-gruppen, men denne gruppen var mer heterogen (fig 2a). Det var ingen klar korrelasjon mellom gruppene definert ut fra genuttrykk og morfolo- gisk definerte undergrupper (centroblasttype, polymorf type og immunoblastisk type). Undergruppene var ikke korrelert til kjente kliniske risikofaktorer. Bcl-2/B-cellereseptorgen-translokasjon $(\mathrm{t}(14 ; 18)$ og c-rel-am- plifikasjon (gen på kromosomarm 2p) var utelukkende påvist i germinalsentercelletypen (fig 2b). De tre molekylære gruppene hadde ulik prognose (fig 2c). Disse funnene er nå bekreftet hos pasienter som har fått anti-CD20-behandling i tillegg til kjemoterapi (13). Utover de gener som definerer de to hovedgruppene av DLBCL, er det andre gener som også har betydning for prognosen. Disse andre genene ble delt inn i to grupper som benevnes genuttrykkssignaturer. De to signaturene blir kalt «stromal-1» og «stromal-2». Stromal-1-signaturen reflekterer avleiring av ekstracellulær matriks og infiltrasjon med histiocytter og er relatert til god prognose, mens stromal-2-signaturen reflekterer tetthet av kapillarer i selve tumorvevet og er relatert til dårlig prognose (13).

Videre analyser har vist at det er ulike genetiske mekanismer som ligger bak patogenesen av ABC- og GCB-lymfomene (fig 2b), og at de derfor bør ses på som ulike lymfomentiteter $(14,15)$. Den samme inndelingen kan med noen begrensninger fastsettes ved hjelp av immunhistokjemisk undersøkelse (16), og denne metoden benyttes ved rutinebesvarelser for nærmere karakterisering av DLBCL.

En annen forskningsgruppe fant tre ulike subgrupper av DLBCL med ulik prognose(17). Genene som definerer disse subgruppene er henholdsvis relatert til B-cellereseptoraktivering, kritiske serin/treonin fosforyleringssignalveier og apoptose. Hittil er det ikke påvist at disse subgruppene har felles underliggende genetiske avvik. Inndelingen av diffuse storcellede B-cellelymfomer i gruppene ABC og GCB er akseptert internasjonalt, og har kommet med i den nye WHO-klassifikasjonen av lymfomer (1).

\section{Primære mediastinale}

\section{$B$-cellelymfomer (PMBCL)}

PMBCL utgjør en tredje distinkt type av DLBCL med forskjellig genuttrykk, genetikk og prognose i forhold til ABC- og GCBundergruppene (9). Denne typen opptrer fortrinnsvis med en stor mediastinaltumor, har et aggressivt klinisk bilde, ikke sjelden med dyp venetrombose i mediastinum eller infraklavikulærregionen og kompresjon av vener i mediastinum med klinisk v. cava superiorsyndrom. PMBCL opptrer typisk hos yngre kvinner. Behandlingsresultatene er varierende, men relativt gode med aggressiv kjemoterapi. Også ordinære DLBCL kan opptre i mediastinum og det kan være vanskelig å skille ut PMBCL fra DLBCL og i noen tilfeller også fra Hodgkins lymfom. Endringer på kromosom 9p er ofte påvist ved PMBCL. PMBCL kan relativt enkelt skilles fra andre diffuse storcellede B-cellelymfomer ved at de har et genuttrykk som i mange henseender minner om Hodgkins lymfom, at flere gener lokalisert til kromosomarm 9p ofte er overuttrykt (JAK2, PDL1, PDL2) og at prognosen ved adekvat behandling er relativt $\operatorname{god}(9)$. 
Mantelcellelymfomer

I en studie med 101 biopsier (8), ble det påvist 48 gener som hadde høyere uttrykk i MCL enn i de andre undersøkte lymfomene (DLBCL og lymfocytære lymfomer), hvorav 28 var assosiert med proliferasjon. Uttrykket av de proliferasjonsassosierte genene hadde størst utsagnskraft med henblikk på overlevelse. Mantelcellelymfomenes kjennetegn er en translokasjon der syklin D1-genet kommer under kontroll av forsterkeren (enhancer) til Ig tung kjede $(\mathrm{t}(11 ; 14))$ med påfølgende økt syklin D1-ekspresjon. Det ble imidlertid identifisert ni lymfomer med morfologi som mantelcellelymfom og med samme genuttrykksmønster, men som var $\mathrm{t}(11 ; 14)$-negative og hadde normal syklin D1-ekspresjon. Flere av disse hadde imidlertid økt uttrykk av andre syklinassosierte gener (syklin D2 og D3). Disse funnene bekrefter at økt proliferasjon er en sentral mekanisme ved MCL, og at undergrupper med relativt kort levetid (med den gitte behandling) kan identifiseres. I en nylig avsluttet nordisk multisenterstudie på 170 pasienter med MCL der pasientene fikk mer intensiv behandling enn tidligere, har man oppnådd oppsiktsvekkende gode resultater med et platå i hendelsesfri overlevelse på ca. $65 \%$ etter fem år (18). Interessant i denne sammenheng er at proliferasjon, målt ved uttrykk av det celleaktiveringsrelaterte proteinet Ki67, var den eneste faktor av prognostisk betydning i multivariatanalyse.

\section{Follikulære lymfomer}

Biopsier fra 191 pasienter med ubehandlet follikulært lymfom ble delt $i$ et treningssett og et valideringssett (10). Det interessante med denne studien var at gener av størst betydning for prognose var uttrykt i de reaktive immunrelaterte cellene. En signatur som innebar en god prognose, besto av gener som var høyt uttrykt i de reaktive T-cellene og i makrofager og en annen signatur var høyt uttrykt i makrofagrekken og/eller i dendrittiske celler og innebar en dårlig prognose (tab 2). Den prognostiske verdien var igjen uavhengig av kliniske variabler. Undersøkelsene viser at det er genuttrykket i de reaktive cellene som omgir tumorcellene, som er viktigst for prognosen.

En annen gruppe fant til dels andre grupper av gener som er relatert til prognose (19). Genene som er relatert til dårlig prognose var cellesykluskontrollgener, gener involvert i DNA-syntese, metabolisme og aktivering av ulike signalveier. Genene relatert til god prognose er delvis de samme som beskrevet ovenfor, og var relatert til T-celleog makrofaginfiltrasjon.

\section{Burkitts lymfom}

Denne typen lymfom (BL) er den raskest voksende av alle maligne tumorer. For få år siden var prognosen dårlig, men den er nå blitt mye bedre med bruk av intensiv, leukemiliknede kjemoterapi. Det er derfor av stor
Tabell 2 Prediktiv utsagnskraft av genuttrykkssignaturer i follikulære lymfomer. Norsk versjon etter tillatelse (10)

\begin{tabular}{|c|c|c|c|}
\hline Genuttrykkssignatur & $\begin{array}{l}\text { P-verdi for bidrag } \\
\text { til modellen i testsettet }\end{array}$ & $\begin{array}{l}\text { Relativ dødsrisiko } \\
\text { (95\% KI) }\end{array}$ & $\begin{array}{l}\text { Effekt av økt genuttrykk } \\
\text { på overlevelse }\end{array}$ \\
\hline Immunrespons 1 & $<0,001$ & $0,15(0,05-0,46)$ & Gunstig \\
\hline Immunrespons 2 & $<0,001$ & $9,35(3,02-28,90)$ & Ugunstig \\
\hline
\end{tabular}

betydning å skille Burkitts lymfom fra andre lymfomtyper. Burkitt-liknende lymfom (BLL) forekommer noe hyppigere enn Burkitts lymfom, har litt avvikende morfologi, men også disse er svært hurtigvoksende og skal ha tilsvarende behandling. I den siste reviderte versjonen av WHO-klassifikasjonen (1) defineres ikke lenger Burkitt-liknende lymfom som en egen entitet.

303 tilfeller av aggressive B-cellelymfomer ble undersøkt, og alle 25 tilfeller som histologisk ble klassifisert som Burkitts lymfom, ble også molekylært funnet å ha et typisk genuttrykk forenlig med denne diagnosen (11). Av 20 biopsier histologisk forenlig med Burkitt-liknende lymfom, var 19 tilfeller molekylært typisk for Burkitts syndrom. Ni tilfeller som var histologisk forenlig med DLBCL hadde et genuttrykk forenlig med Burkitts lymfom. Slikt lymfom adekvat behandlet med aggressiv kjemoterapi hadde en langt bedre prognose enn de som var behandlet med mindre aggressiv kjemoterapi. Så godt som identiske funn er samtidig beskrevet av Hummel og medarbeidere (20). Alle tilfeller av Burkitts syndrom har en c-myc-translokasjon der dette proliferasjonsassosierte genet kommer under kontroll av forsterkeren til Ig tung eller lett kjede. Dette fører til økt, ukontrollert ekspresjon av c-myc. Imidlertid foreligger c-myctranslokasjon også i 5-10\% av tilfellene ved DLBCL. Mikromatriseanalyse av Burkitts syndrom viste likevel en annerledes genprofil enn DLBCL med c-myc-translokasjon, muligens fordi denne translokasjonen er en primær hendelse ved patogenesen av Burkitts syndrom.

\section{Diskusjon}

Flere av målsettingene med prosjektet nevnt i innledningen anses som oppnådd (sikrere diagnostikk, nye klinisk relevante undergrupper, prognostisk betydning av uttrykk av sett av gener). Andre forskningsgrupper meddeler funn som støtter dem som her er nevnt, blant annet på DLBCL (17), PMBCL (20) og Burkitts syndrom (20). Tilgang til store materialer gjennom internasjonalt samarbeid og kobling til kliniske data, har vært en viktig grunn til prosjektets suksess.

DNA-mikromatriseanalyser er også utført på andre lymfomtyper, som ulike typer av Tcellelymfomer (22-24). I en av disse studiene (22) har man påvist at angioimmunoblastiske T-cellelymfomer har opprinnelse fra intrafollikulære T-celler og at disse lymfomer skiller seg ut fra perifere T-cellelymnormale T-celler er imidlertid nødvendig for å oppdage potensielt flere subgrupper innen gruppen perifere T-cellelymfomer. Studienes betydning er styrket ved immunhistokjemiske undersøkelser som viser at genuttrykket translateres på proteinnivå slik at de samme undergruppene grovt sett kan identifiseres ved immunhistokjemiske metoder (16).

Måling av genuttrykk ved bruk av mikromatriser viser på en unik måte hvilke signalveier som er aktive i de ulike lymfomentitetene, for eksempel signalveier som fører til celleaktivering og -proliferasjon. Dersom disse signalveiene er aktivert på en unik måte i lymfomcellene sammenliknet med deres «normale motstykker» blant lymfocyttene, kan de være gjenstand for målrettet behandling. Ny, målrettet behandling basert på våre funn og funn fra tilsvarende undersøkelser $\mathrm{i}$ andre forskergrupper er allerede $\mathrm{i}$ klinisk utprøving (25). Et eksempel er behandling rettet mot NFKB (26). Denne transkripsjonsfaktoren er høyt uttrykt og synes å ha betydning for fenotypen i enkelte typer av lymfomer som ABC-undergruppen av DLBCL, Hodgkins lymfom og MCL.

Våre undersøkelser er retrospektive og de må derfor bekreftes i prospektive analyser. Dette er viktig også for å avklare om den prognostiske verdi av genuttrykkssignaturene er relevante også med dagens behandling. Resultater fra flere forskningsgrupper tyder for eksempel på at undergruppen av DLBCL med dårligst prognose (ABC) har størst nytte av pan-B-celleantistoffet rituximab rettet mot CD20-antigenet i tillegg til kjemoterapi (27-29). Imidlertid fant vi nylig at det fortsatt var en signifikant forskjell i overlevelse mellom ABC- og GCB-subtypene ved DLBCL behandlet med rituximab (13).

Måling av genuttrykk ved hjelp av mikromatriser er komplisert og innebærer mange fallgruver. For at analysene skal bli anvendbare i rutinediagnostikken, må de forenkles og være reproduserbare for alle laboratorier som benytter slik diagnostikk. Metodene er nå mer reproduserbare enn for få år siden, men de økonomiske kostnadene er fortsatt betydelige. Radiumhospitalet tar nå del i en prospektiv studie med de samme sentre som deltakere.

\section{Sammenfatning}

Histopatologisk diagnostikk av maligne lymfomer skal i dag kompletteres med im- fomer, UNS. Mer kunnskap om biologien av 
munfenotypiske og molekylære analyser for korrekt diagnostikk. Om få år vil trolig mikromatriseanalyser på gennivå eller på proteinnivå bli inkludert i rutinediagnostikken, men laboratoriene må ha ressurser og personale som behersker de nye teknikkene. Begrepet «øvelse gjør mester», kan også gjøres gjeldende for komplisert vevsdiagnostikk av maligne lidelser. Eksempelvis er nå slik diagnostikk i England og Tyskland sentralisert til 5-6 sentre i hvert av landene. I Norge er ikke en tilsvarende sentralisering gjennomført. Histologisk og molekylærbiologisk lymfomdiagnostikk i Norge bør være gjenstand for sentral revisjon, for eksempel ved universitetssykehus.

Oppgitte interessekonflikter: Ingen

\section{Litteratur}

1. Swerdlow SH, Campo E, Harris NL et al. WHO classification of tumours of haematopoetic and lymphoid tissue.. Lyon: IARC press, 2008.

2. Jerkemann M, Arnesson C, Carlsson K et al. Rapport för år 2000-2006. Lund: Svenska Lymfomregistret, 2009

3. The International non-Hodgkin's lymphoma prognostic factor project. A predictive model for aggressive non-Hodgkin's lymphoma. N Engl J Med 1993: 329: 987-94.

4. Hasenclever D, Diehl V. A prognostic score for advanced Hodgkin's disease. International Prognostic Factors Project on advanced Hodgkin's disease. N Engl J Med 1998; 339: 1506-14.

5. Solal-Celigny P. Roy P, Colombat P et al. Follicular lymphoma international prognostic index. Blood 2004; 104: 1258-65

6. Forus A, Sørlie T, Børresen-Dale A-L et al. Mikromatriser i kreftforskning - nå trenger vi ikke lete bare under gatelyktene! Tidsskr Nor Lægeforen 2001: 121: 2498-503

7. Rosenwald A, Wright G, Chan WC et al. Lymphoma/Leukemia Molecular Profiling Project. The use of molecular profiling to predict survival after chemotherapy for diffuse large B-cell lymphoma. N Engl J Med 2002; 346: 1937-47.
8. Rosenwald A, Wright G. Wiestner A. et al. The proliferation gene expression signature is a quantitative integrator of oncogenic events that predicts survival in mantle cell lymphoma. Cancer Cell 2003; 3: 185-97.

9. Rosenwald A, Wright G, Yu X et al. Molecular diagnosis of primary mediastinal $B$ cell lymphoma identifies a clinically favorable subgroup of diffuse large B Cell lymphoma related to Hodgkin lymphoma. J Exp Med 2003: 198: 851-62.

10. Dave SS, Wright G, Tan B et al. Survival following diagnosis of follicular lymphoma is predicted by molecular features of non-malignant tumor-infiltrating immune cells. N Engl J Med 2004; 351: 2159-69

11. Dave S, Fu, K, Wright $G$ et al. Molecular diagnosis of Burkitt lymphoma. N Engl J Med 2006; 354 $2431-42$

12. Alizadeh AA, Eisen MB, Davis RE et al. Distinct types of diffuse large $B$-cell lymphoma identified by gene expression profiling. Nature 2000; 403: $503-11$

13. Lenz G. Wright GW, Dave SS et al. Stromal gene signatures in large-B-cell lymphomas. N Engl J Med 2008; 359: 2313-23.

14. Staudt LM, Dave S. The biology of human lymphoid malignancies revealed by gene expression profiling. Adv Immunol 2005: 87: 163-208

15. Bea S, Zettl A, Wright G et al. Lymphoma/Leukemia Molecular Profiling Project. Diffuse large Bcell lymphoma subgroups have distinct genetic profiles that influence tumor biology and improve gene-expression-based survival prediction. Blood 2005; 106: 3183-90.

16. Hans CP, Weisenburger DD, Greiner TC et al. Confirmation of the molecular classification of diffuse large B-cell lymphoma by immunohistochemistry using a tissue microarray. Blood 2004: 103: $275-82$

17. Shipp MA, Ross KN, Tamayo $P$ et al. Diffuse large B-cell lymphoma outcome prediction by geneexpression profiling and supervised machine learning. Nat Med 2002; 8: 68-74.

18. Geisler CH, Kolstad A, Laurell A et al. Long-term progression-free survival of mantle cell lymphoma after intensive front-line immunochemo-therapy with in vivo-purged stem cell rescue: a nonrandomized phase 2 multicenter study by the Nordic Lymphoma Group. Blood 2008; 112: 2687-93.

19. Glas AM, Kersten MJ, Delahaye LJ et al. Gene expression profiling in follicular lymphoma to assess clinical aggressiveness and to guide the choice of treatment. Blood 2005; 105: $301-7$.
20. Hummel M, Bentink S, Berger $\mathrm{H}$ et al. A biologic definition of Burkitt's lymphoma from transcriptional and genomic profiling. N Engl J Med 2006; 354 2419-30.

21. Savage KJ, Monti S, Kutok JL et al. The molecular signature of mediastinal large B-cell lymphoma differs from that of other diffuse large B-cell lymphomas and shares features with classical Hodgkin lymphoma. Blood 2003; 102: 3871-9.

22. de Leval L, Rickman DS, Thielen $C$ et al. The gene expression profile of nodal peripheral T-cell lymphoma demonstrates a molecular link between angioimmuno-blastic T-cell lymphoma (AITL) and follicular helper T (TFH) cells. Blood 2007: 109. 4952-63.

23. Lamant L, de Reyniès A, Duplantier MM et al. Gene-expression profiling of systemic anaplastic large-cell lymphoma reveals differences based on ALK status and two distinct morphologic ALK+ subtypes. Blood 2007; 109: 2156-64.

24. Piccaluga PP, Agostinelli C, Califano A et al. Gene expression analysis of peripheral $T$ cell lymphoma unspecified, reveals distinct profiles and new potential therapeutic targets. J Clin Invest 2007, 117: 823-34

25. Abramson JS, Shipp MA. Advances in the biology and therapy of diffuse large B-cell lymphoma: moving toward a molecularly targeted approach. Blood 2005; 106: 1164-74.

26. Jost PJ, Ruland J. Aberrant NF-kappaB signalling in lymphoma: mechanisms, consequences and therapeutic implications. Blood 2007; 109: 2700-7.

27. Liu YY, Leboeuf C. Shi JY et al. Rituximab plus CHOP (R-CHOP) overcomes PRDM1-associated resistance to chemotherapy in patients with diffuse large B-cell lymphoma. Blood 2007: 110 339-44.

28. Wilson KS, Sehn LH, Berry B et al. CHOP-R therapy overcomes the adverse prognostic influence of $\mathrm{BCL}-2$ expression in diffuse large B-cell lymphoma. Leuk Lymphoma 2007; 48: 1102-9.

29. Nyman H, Adde M, Karjalainen-Lindsberg ML et al. Prognostic impact of immunohistochemically defined germinal center phenotype in diffuse large Bcell lymphoma patients treated with immunochemotherapy. Blood 2007; 109: $4930-5$.

Manuskriptet ble mottatt 1.6. 2009 og godkjent 24.9. 2009. Medisinsk redaktør Michael Bretthauer. 